Thomson, Sir Charles Wheatstone, Prof. Huxley, Dr. Carpenter, Sir Henry Holland, Prof. Stokes, Prof. Allman, Dr. Hooker, Mr. Siemens, and others. Under the guidance of Captain Nares, the commander of the Challenger, Prof. Wyville Thomson, the scientific leader of the expedition, and other members of the staff, the visitors inspected with keen interest all the fittings and appliances with which the handsome ship has been furnished for carrying out the purposes of the expedition. Everything appeared complete, and the perfection and abundance of the preparations excited the universal admiration of the visitors. Government, in this instance, have acted with the most praiseworthy liberality. The ship itself has a greater tonnage than the three ships together which formed the expedition of Cook in 1772 . After the visitors had completed their inspection, they were entertained to an ample luncheon in the wardroom, under the presidency of Captain Nares. A few toasts were drunk and a few very brief speeches made, in which some well-deserved compliments were paid to those most intimately connected with the expedition. Dr. Carpenter felt sure that under Prof. Thomson's superintendence "no fact would be let go, and that every fact would find its place and its value when results came to be worked out ;" while Prof. Thomson said that if the vessel were not thoroughly equipped, it was the fault of the scientific staff; they had met with every encouragement from Government to ask for what is necessary.

We are sorry to hear that the Challenger has already met with a little rough treatment from some of the elements she is bound to explore. In the fierce gales which prevailed on Sunday, she lost her cutter, and was compelled to put into Deal. We believe no serious delay will result from this accident, which, we hope, may be the only one of the kind the party may meet with. According to present arrangements she leaves Portsmouth on Monday next.

We cannot, however, but express our regret that the party were allowed to set off on an absence from England which may be prolonged for four years, animated, in their voluntary exile, by no motive but a desire to promote the interests of science, without some more official and more extended acknowledgment from their scientific brethren throughout the country than a few after-lunch speeches on board the corvette. Our contemporary $P u n c h$ has, however, given his accolade to the expedition in some spirited lines:-

"Broadside guns have made room to ship batteries magnetic, Apparatus turns out ammunition,

From main-deck to ground-tier I'm a peripatetic

Polytechnic marine exhibition."

\section{PROCEEDINGS OF ZOOLOGICAL COLLECTORS}

M R. T. K. SALMON has lately transmitted to his agent, Mr. E. Gerrard, jun., of Camden Town, a fine collection of birds from the province of Antioquia, United States of Columbia. Amongst them are specimens of a new Humming Bird, which Mr. Gould has described as Adelomyia cervina. Mr. Salmon has now pushed forward into the upper valley of the Cauca, where he will enter upon untrodden ground.

Mr. Henry M. Whitely has also been very active lately in the district he is now exploring, in the Andes of Caravaya, east of Cuzco, Peru. His last collection contains some very fine species of Tanagers, previously only known from d'Orbigny's specimens in the Paris Museum. There are also several remarkable humming birds in $\mathrm{Mr}$. Whitely's collection, one of which, being new to science, Mr. Gould has named Iolama Whitelyana, after its discoverer.

Letters have been received from $\mathrm{Mr}$. Charles $\mathrm{R}$.
Thatcher, who is en route for the Philippines, announcing his arrival at Yokohama, viâ San Francisco, and immediate departure for his destination. Mr. Thatcher will attend principally to the land-shells and birds of the Philippine Archipelago.

P. L. S.

\section{NOTES}

ThE Italian Government has ordered a massive gold medal, with a suitable inscription, to be prepared for presentation to Dr. Livingstone. The medal was to be ready by the $3^{\text {rd inst. }}$ and was to be consigned-with an official letter addressed in the king's name to the great traveller - to Sir Bartle Frere, in the hope that he may either present it in person, or forward it to him by some safe hand. The Commenảatore Negri Cristofero, President of the Italian Geographical Society, has been the prime mover in bringing about the gratifying recognition of Livingstone's labours in behalf of Science and humanity; and the Italians generally appear to be delighted with the ideal of being the first to tender him this national; proof of the high estimation in which they hold him. On one side the medal bears the bust of the king, with the legend "Vittorio Emmanuele II. Rè d'Italia," and on the obverse "A Davide Livingstone, Vittorio Emmanuele II. 1872."

AT a meeting of the Geographical Society on Monday night, Mr. Francis Galton, who occupied the chair, stated that he believed Sir Bartle Frere would probably be in Alexandria that night, and that Lieut. Grandy, leader of the "Livingstone Congo Expedition," would land in Sierra Leone about the $15^{\text {th }}$ of this montl. Mr. Galton also announced that a long list of astronomical observations had been received from Livingstone by Sir Thomas Maclear, at the Cape, who says they will take three or four months to reduce.

We greatly regret to have to record the death, on Monjay last, of John Keast Lord, the manager of the Brighton Aquarium. We learn from the Brigliton Daily Noiv that Mr. Lord was Iaid up with a severe attack of paralysis some months since, but though it was known that he was not in the enjoyment of robust health, it was far from being generally thought that his indisposition would so soon be brought to a fatal termination. Originally a captain in the Royal Artillery, in which capacity he served in the Crimean war, and took part in the battle of Balaclava, $\mathrm{Mr}$. Lord seems to have always entertained an intense love for the study of natural history; and at the close of the ${ }_{\text {R }}$ Russian campaign he quitted the army for a field in every way more congenial to his tastes. He now devoted himself to the study of nature in good earnest, and spent some time in Vancouver Island, which he appears to have thoroughly investigated. The results of his labours were afterwards given to the world in "The Naturalist in Vancouver Island." Mr. Lord afterwards served on the North American Boundary Commission, and later on was engaged by the Viceroy of Egypt to report upon certain charac. teristics of that country. It was from Egypt, we believe, that he was called by the directors of the Aquarium to take the appointment for which he was so peculiarly fitted.

THe University of Cambridge has passed a resolution by which in future successful candidates in Moral Science can present themselves for the next Natural Science Tripos, and vice versâ.

An examination for minor scholarships for students intending to commence residence at Cambridge next October will be held at Clare College on Wednesday, March 25, 1873. One of these of the value of $50 l$. tenable for $3 \frac{1}{2}$ years, will be awarded for Natural Sciences. The subject; are Chenistry, Chemical Physics (including Light, Heat, and Electricity), Comparative Anatomy and Physiology, and Geology. Excellence in any two 